MATEC Web of Conferences 22,05022 (2015)

DOI: $10.1051 /$ matec conf/ 20152205022

(C) Owned by the authors, published by EDP Sciences, 2015

\title{
A Study on Differences of China's Regional Economic Development Level Based on Cluster Analysis
}

\author{
Yaoyuan Qi \\ Donlinks School of Economics and Management, University of Science and Technology Beijing, Beijing, China
}

\begin{abstract}
An evaluation index system of regional economic development is established in this paper and STATA11.0 is used in the cluster analysis on samplings of 31 provincial regions. Results indicate that the economy of most regions is still in a backward stage except a few developed regions and the economic polarization of China is quite serious. This study provides a reference for the coordinated and rapid development of China's economy.
\end{abstract}

Keywords: regional economic development; cluster analysis; difference

\section{INTRODUCTION}

It astonishes western developed countries that the GDP of China has increased continuously in recent years. In 2012, the GDP of China was as high as 51.62821 trillion yuan. China has become the second largest economic entity with the exception of the United States. However, the gap of regional development still cannot be covered up by this. There are many aspects of reasons for regional economic development differences. It is unable to determine the degree of difference, and reasons only by experience-based judgment and simple data analysis. The mystery of existing differences of various regions can be clearly known with the help of cluster analysis of multivariate statistics.

It is the objective requirement of harmonious development of socialism and the realization of "Chinese Dream" that the gap of regional economic development should be narrowed down so as to realize coordinated development of regions.

\section{LITERATURE REVIEW}

By looking up and organizing relevant literatures of regional economic gap, it can be known that academic studies at home and abroad mainly involve the measurement and variation trend of China's regional economic gap as well as causes and countermeasures for China's regional economic gap.

As for the aspect of regional development trend in China, Minliang Zhou ${ }^{[1]}$ believes that the gap of Three Regions, namely eastern-central-western, was widened in 1990s compared to 1980s. Yifu Lin and Peilin Liu ${ }^{[2]}$ carry out a study on provincial economic gap of mainland China with variation coefficient and Gini coefficient, believing that the regional gap in mainland China has become more and more serious since 1990s. Weihua Guan ${ }^{[3]}$ also believes that the regional gap of China was narrowed down during $1960 \mathrm{~s}$ and 1990s. But the gap began to be widened after 1990s.

Although domestic scholars use different methods on the research of China's regional gap, opinions on the size and trend of regional gap are basically consistent. They believe that the regional economic gap has been widened since1990s and it has expanded to a relatively serious degree.

As for the aspect of causes and countermeasures of regional economic industries, Yifu Lin and Peilin Liu ${ }^{[2]}$ indicate from the perspective of regional policies that the development strategy of the central and western China is inconsistent with the principle of comparative advantage, leading to an increasingly widened economic disparity between the central and western China and the eastern China. They believe that governments of central and western regions should optimize local incremental investment and increase the viability of local enterprises. Xiushan Chen and Ying $\mathrm{Xu}^{[4]}$ believe that quality, quantity, service efficiency and allocation efficiency of factor input are reasons for the significant difference of China's regional economy. Wenwu Zhang and Qi Liang ${ }^{[5]}$ put forward that the unbalanced distribution human capital stock in various provinces and cities is also the reason for the continuously widened regional economic development gap. It is obliged to formulate policies that guarantee and promote the flow of labors in China. From the perspective of financial allocation, Fengwei Liu ${ }^{[6]}$ believes that reasonable transfer payment from the exchequer can effectively narrow down the gap of regional economy.

Xiaolu Wang and Gang Fan ${ }^{[7]}$ believe that foreign direct investment, gathering of private capital in the eastern part and the increase of productivity difference have intensified the gap between the central and western part of China and the eastern China. They propose that both hard and soft environment of investment in the central and western part of China should be re- 
formed. From the perspective of trade, $\mathrm{Bin} \mathrm{Li}$ and Kaijun Chen ${ }^{[8]}$ hold that the difference of foreign trade among provinces and cities in China is an important inducing factor for the regional gap.

\section{A BRIEF INTRODUCTION OF THE MODEL}

\subsection{Measurement model}

The idea of cluster analysis is to carry out quantitative measurement on the similarity level and affinity of samples without prior knowledge according to characteristics of samples so as to make comparisons and differentiate various types. Results of numerical analysis can be clearly expressed by a pedigree chart acquired from cluster analysis. It is quite helpful for the objective analysis and reasonable evaluation on the gap of regional economic development level.

There are numerous kinds of clustering methods. STATA has two major methods. One is K-Means Cluster and the other is Hierarchical Cluster ${ }^{[9]}$. This paper analyzes economic development situations of 31 provinces and cities (regions) in 2012 with the method of Average-Linkage Cluster Analysis in Hierarchical Cluster.

\subsection{Index selection}

There are huge differences in territorial type, size and population of provinces and cities (regions). It is incomparable if the total index is only considered in the comparison of economic development level of various regions. Therefore, this paper adopts the method of combining total index and per capita index to give objective and comprehensive evaluation on the economic development of each region from 17 indicators of six aspects, namely national economic accounting (gross regional production, per capita gross regional production, per capita value added of the primary industry, per capita value added of the second industry, per capita value added of the third industry, per capita industrial added value), employment and wage (average wage of on-post staff of urban units),

Table 1. Evaluation indexes of regional economic development

\begin{tabular}{|c|c|c|}
\hline Variables & Indexes & Explanations \\
\hline $\mathbf{X}_{1}$ & Gross regional production (billion yuan) & $\begin{array}{l}\text { Reflecting the final results of production activities of a } \\
\text { region within a certain period of time }\end{array}$ \\
\hline $\mathbf{X}_{2}$ & $\begin{array}{l}\text { Per capita gross regional production (yuan/per } \\
\text { capita) }\end{array}$ & $\begin{array}{l}\text { Reflecting the average level of regional economic de- } \\
\text { velopment }\end{array}$ \\
\hline $\mathbf{X}_{3}$ & $\begin{array}{l}\text { General budget revenue of local finance (bil- } \\
\text { lion yuan) }\end{array}$ & $\begin{array}{l}\text { Reflecting regional economic strength and public facili- } \\
\text { ties construction ability }\end{array}$ \\
\hline $\mathbf{X}_{4}$ & Resident consumption level (yuan) & $\begin{array}{l}\text { Reflecting living standard and purchasing power of } \\
\text { regional residents }\end{array}$ \\
\hline $\mathbf{X}_{5}$ & $\begin{array}{l}\text { Total retail sales of consumer goods (billion } \\
\text { yuan) }\end{array}$ & Reflecting regional consumption and management ability \\
\hline $\mathbf{X}_{6}$ & $\begin{array}{l}\text { Year-end balance of RMB saving deposits of } \\
\text { urban and rural residents (billion yuan) }\end{array}$ & $\begin{array}{l}\text { Reflecting living standard and potential purchasing pow- } \\
\text { er of urban and rural residents }\end{array}$ \\
\hline $\mathbf{X}_{7}$ & Total fixed asset investment (billion yuan) & $\begin{array}{l}\text { Reflecting regional fixed-asset investment scale, struc- } \\
\text { ture and development speed }\end{array}$ \\
\hline $\mathbf{X}_{8}$ & Commercial housing sales (billion yuan) & Reflecting regional commercial housing sale situation \\
\hline $\mathbf{X}_{9}$ & $\begin{array}{l}\text { Average selling price of commercial housing } \\
\text { (yuan/square meter) }\end{array}$ & $\begin{array}{l}\text { Reflecting the average price level of regional commercial } \\
\text { housing }\end{array}$ \\
\hline $\mathbf{X}_{10}$ & $\begin{array}{l}\text { Total investment of foreign-invested enterprise } \\
\text { (million USD) }\end{array}$ & Reflecting the attraction power of regional foreign trade \\
\hline $\mathbf{X}_{11}$ & $\begin{array}{l}\text { Per capita total export-import volume } \\
\text { (USD/per capita) }\end{array}$ & $\begin{array}{l}\text { Reflecting the development level of regional foreign } \\
\text { trade and business competition ability }\end{array}$ \\
\hline $\mathbf{X}_{12}$ & Per capita industrial added value (yuan) & $\begin{array}{l}\text { Reflecting the development level of regional industrial } \\
\text { production }\end{array}$ \\
\hline $\mathbf{X}_{13}$ & $\begin{array}{l}\text { Per capita value added of the primary industry } \\
\text { (yuan) }\end{array}$ & Reflecting regional agriculture development level \\
\hline $\mathbf{X}_{14}$ & $\begin{array}{l}\text { Per capita value added of the second industry } \\
\text { (yuan) }\end{array}$ & Reflecting regional industrialization level \\
\hline $\mathbf{X}_{15}$ & $\begin{array}{l}\text { Per capita value added of the third industry } \\
\text { (yuan) }\end{array}$ & $\begin{array}{l}\text { Measuring regional level of service industry and urbani- } \\
\text { zation }\end{array}$ \\
\hline $\mathbf{X}_{16}$ & Per capita net income of rural residents (yuan) & $\begin{array}{l}\text { Reflecting regional average income level of rural resi- } \\
\text { dents }\end{array}$ \\
\hline $\mathbf{X}_{17}$ & $\begin{array}{l}\text { Average wage of on-post staff of urban units } \\
\text { (yuan) }\end{array}$ & $\begin{array}{l}\text { Reflecting regional average wage of on-post staff of } \\
\text { urban units }\end{array}$ \\
\hline
\end{tabular}


fixed asset investment and real estate (total fixed asset investment, commercial housing sales, average selling price of commercial housing), foreign trade (per capita total export-import volume of destinations and sources, total investment of foreign-invested enterprise), finance (general budget revenue of local finance), people's livelihood (RMB saving deposits of urban and rural residents, per capita net income of rural residents) and total retail sales of consumer goods (as shown in Table 1).

In this paper, 17 economic indexes of 31 provincial regions in 2012 are obtained from China Statistical Yearbook 2013 and the website retrieval of National Bureau of Statistics. Original data are not listed here due to the limited length of this paper.

\section{EMPIRICAL STUDY}

\subsection{Process of clustering}

This paper uses STATA11.0 data processing system as the tool for statistics analysis. Units of selected indexed are not the same, so it is incomparable in cluster analysis. Thus, original data are ordered by cluster analysis after standardized process and descriptive statistics. The process of clustering is shown in Table 2.

Table 2. Clustering process of regional economic development level.

\begin{tabular}{|llll|}
\hline & _clus_1_id & _clus_1_ord & _clus_1_hgt \\
\hline Beijing & 1 & 1 & 4.534452 \\
\hline Tianjin & 2 & 9 & 5.9346876 \\
\hline Hebei & 3 & 2 & 8.8982343 \\
\hline Shanxi & 4 & 3 & 0.79097142 \\
\hline Inner Mongolia & 5 & 16 & 1.3492566 \\
\hline Liaoning & 6 & 23 & 1.5028296 \\
\hline Jilin & 7 & 12 & 1.3032403 \\
\hline Heilongiiang & 8 & 17 & 0.82112484 \\
\hline Shanghai & 9 & 18 & 2.3694233 \\
\hline Jiangsu & 10 & 4 & 1.5177614 \\
\hline Zhejiang & 11 & 22 & 1.0680122 \\
\hline Anhui & 12 & 27 & 1.9977645 \\
\hline Fujian & 13 & 7 & 1.2849961 \\
\hline Jiangxi & 14 & 8 & 1.6631815 \\
\hline Shandong & 15 & 14 & 1.0802504 \\
\hline Henan & 16 & 20 & 1.737903 \\
\hline Hubei & 17 & 31 & 3.1208559 \\
\hline Hunan & 18 & 24 & 0.79048985 \\
\hline Guangdong & 19 & 28 & 1.1025764 \\
\hline Guangxi & 20 & 25 & 2.131315 \\
\hline & & & \\
\hline
\end{tabular}

\begin{tabular}{|llll|}
\hline Hainan & 21 & 29 & 0.6324261 \\
\hline Chongqing & 22 & 30 & 2.3816644 \\
\hline Sichuan & 23 & 26 & 3.9857724 \\
\hline Guizhou & 24 & 21 & 4.2009003 \\
\hline Yunnan & 25 & 5 & 3.1945837 \\
\hline Tibet & 26 & 6 & 2.4461945 \\
\hline Shanxi & 27 & 13 & 7.5738251 \\
\hline Gansu & 28 & 10 & 3.2723932 \\
\hline Qinghai & 29 & 19 & 4.5601193 \\
\hline Ningxia & 30 & 11 & 4.0172432 \\
\hline Sinkiang & 31 & 15 & \\
\hline
\end{tabular}

Clus 1 id stands for sample numbers of 31 regions and clus1_ord stands for the sample number in sequence in the process of clustering. Region names represented by numbers of clus1_ord can be searched with numbers of clus1_id. For example, Beijing (1) is in the closest distance with Shanghai (9). The gap of economic development level between the two is 4.534452. Hebei (3) is in the closest distance with Henan (16). The gap of economic development level between the two is only 0.79097142 . The tree diagram (shown in Figure 1) of the cluster analysis can be obtained in accordance with Table 2.

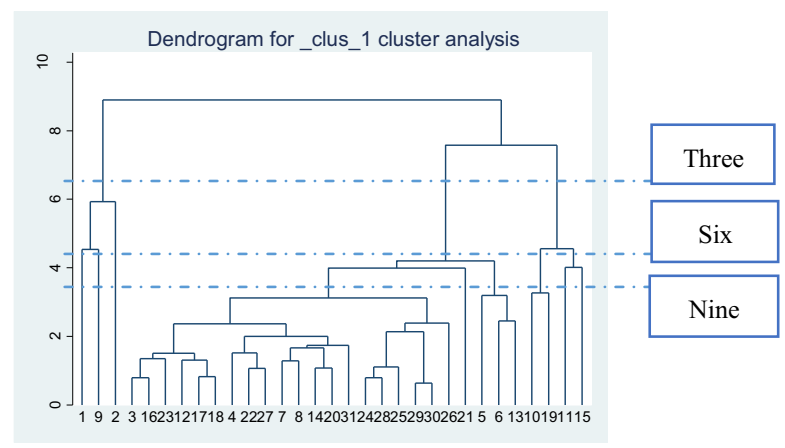

Figure 1. Tree diagram of cluster analysis on regional economic development level difference.

Different threshold values are selected (dotted lines in Figure 1) and 31 samples can be respectively divided into three categories, six categories and nine categories. Specific cases are shown in Table 3.

The dynamic clustering process, mutual relation and trivial difference of regions with different economic development levels can be directly seen from Figure 1 and Table 3.

\subsection{Results analysis}

Conclusions can be drawn as follows according to the above cluster analysis: (1). Beijing, Shanghai and Tianjin are economically developed regions. (2). 
MATEC Web of Conferences

Table 3. Categories of regional economic development level.

\begin{tabular}{|c|c|c|c|c|c|}
\hline \multicolumn{2}{|c|}{ Three categories } & \multicolumn{2}{|c|}{ Six categories } & \multicolumn{2}{|c|}{ Nine categories } \\
\hline Categories & Samples & Categories & Samples & Categories & Samples \\
\hline \multirow[t]{3}{*}{1} & \multirow[t]{3}{*}{ Beijing, Shanghai, Tianjin } & 1 & Beijing & 1 & Beijing \\
\hline & & 2 & Shanghai & 2 & Shanghai \\
\hline & & 3 & Tianjin & 3 & Tianjin \\
\hline \multirow[t]{3}{*}{2} & \multirow{3}{*}{$\begin{array}{l}\text { Hebei, Henan, Sichuan, } \\
\text { Anhui, Hubei, Hunan, Shan- } \\
\text { xi, Chongqing, Shanxi, Jilin, } \\
\text { Heilongjiang, Jiangxi, } \\
\text { Guangxi, Sinkiang, Gui- } \\
\text { zhou, Gansu, Yunnan, } \\
\text { Qinghai, Ningxia, Tibet, } \\
\text { Hainan, Inner Mongolia, } \\
\text { Liaoning, Fujian }\end{array}$} & \multirow[t]{3}{*}{4} & \multirow{3}{*}{$\begin{array}{l}\text { Hebei, Henan, Sichuan, } \\
\text { Anhui, Hubei, Hunan, Shan- } \\
\text { xi, Chongqing, Shanxi, Jilin, } \\
\text { Heilongjiang, Jiangxi, } \\
\text { Guangxi, Sinkiang, Gui- } \\
\text { zhou, Gansu, Yunnan, } \\
\text { Qinghai, Ningxia, Tibet, } \\
\text { Hainan, Inner Mongolia, } \\
\text { Liaoning, Fujian }\end{array}$} & 4 & $\begin{array}{l}\text { Hebei, Henan, Sichuan, Anhui, } \\
\text { Hubei, Hunan, Shanxi, Chong- } \\
\text { qing, Shanxi, Jilin, Heilongjiang, } \\
\text { Jiangxi, Guangxi, Sinkiang, } \\
\text { Guizhou, Gansu, Yunnan, Qing- } \\
\text { hai, Ningxia, Tibet }\end{array}$ \\
\hline & & & & 5 & Hainan \\
\hline & & & & 6 & Inner Mongolia, Liaoning, Fujian \\
\hline \multirow[t]{3}{*}{3} & \multirow{3}{*}{$\begin{array}{l}\text { Jiangsu, Guangdong, } \\
\text { Zhejiang, Shandong }\end{array}$} & 5 & Jiangsu, Guangdong & 7 & Jiangsu, Guangdong \\
\hline & & \multirow[t]{2}{*}{6} & \multirow[t]{2}{*}{ Zhejiang, Shandong } & 8 & Zhejiang \\
\hline & & & & 9 & Shandong \\
\hline
\end{tabular}

Jiangsu, Guangdong, Zhejiang and Shandong are regions that are relatively developed economically. (3). Inner Mongolia, Liaoning, Fujian and Hainan are regions of general economic development level. (4). Other regions are economically undeveloped.

The above results reflect China's regional economic development to some extent: a very few regions are economically developed (Beijing, Shanghai, and Tianjin); coastal regions have obvious advantages in economic development (Jiangsu, Guangdong, Zhejiang, and Shandong); a few regions are general (Hainan, Inner Mongolia, Liaoning, and Fujian); other provinces are generally backward with small gaps. This differs from the state that the economic development level is in line with the geographic variation from coastal regions to central regions and then western regions.

As for the classification results, several regions indexes need special attention. First, three direct-controlled municipalities, namely Beijing, Shanghai and Tianjin, are far ahead. They perform noticeably well in six indexes of the 17 evaluation indexes, per capita GDP, household consumption level, average selling price of commercial housing, per capita value added of the third industry, per capita net income of rural residents and average wage of on-post staff of urban units. It can be seen that people's living standard in three direct-controlled municipalities is indeed superior to that in other regions, and the degree of economic development is also mature.

Second, Jiangsu, Guangdong and Shanghai are outstanding in total investment of foreign-invested enterprise, far surpassing Zhejiang province that ranks the fourth. Besides, Guangdong and Shanghai are also prominent in per capita total export-import volume. Thus, Jiangsu, Guangdong and Shanghai have advantages in attracting foreign investment. As special economic zones that were reformed and opened up the earliest, these regions are positively stimulated by excellent coastlines and developed import and export ports. In addition, Liaoning and Fujian are relatively prominent in total fixed asset investment and total investment of foreign-invested enterprise. Inner Mongolia has prominent advantages in per capita industrial added value for its rich coal reserves, natural gas and iron and steel industry.

At last, other regions are generally backward in economic development. There are united clusters in some regions. For example, Hebei (3), Henan (16), Sichuan (23), Anhui (12), Hubei (17) and Hunan (18) are gathered as a small cluster; Shanxi (4), Chongqing (22), Shanxi (27), Jilin (7), Heilongjiang (8), Jiangxi (14), Guangxi (20) and Sinkiang (31) are gathered as another cluster. However, there is no big difference between the two clusters in the overall level of economic development. They are generally backward.

\section{CONCLUSION AND POLICY SUGGESTIONS}

Balanced development of regional economy is an important factor for national economy. Scientific and reasonable evaluations on regional economic development are of great importance for knowing the overall economic development and adjusting balanced development of different regions.

Through the cluster analysis on economic development indexed of 31 regions in 2012, it can be found that the economic development gap of different regions is quite large. Beijing, Tianjin and Shanghai are economically developed. Coastal regions like Guangdong, Zhejiang, Jiangsu and Shandong are relatively developed in economy. And other regions are generally backward with severe polarization.

According to the results of cluster analysis and reasons for the differences, strategies and suggestions for improving the severely imbalanced economy can be proposed as follows: (1). Drive economy with science and technology. As for economically developed and undeveloped regions, science and technology industrial park and many colleges are gathered in developed regions while the education degree and science and 
technology popularization are relatively low in undeveloped regions. Although it becomes effective slowly that economy is driven by science and technology, the significance of the foundation cannot be ignored. (2). Promote the two-way information circulation system of developed and backward regions. In order to avoid the fact that resources and energies are simply provided by backward regions to developed regions, developed regions should also provide backward regions with sustained help and guidance in terms of economy and science and technology. (3). Increase income level of peasant household. Economically backward regions are undeveloped in industry, financial industry and service industry, financial resources of which mainly rely on agricultural production. Therefore, raising rural income and increasing rural living quality are also important ways of narrowing the gap while the industrial development is taken into account at the same time.

\section{REFERENCES}

[1] Zhou, M.L. 1997. A discussion on regional differences and regional policies, Management World, (1): 174-184.

[2] Lin, Y.F. \& Liu, P.L. 2003. Economic development strategies and regional income gap in China, Economic Research, (3): 19-25.

[3] Guan, W.H., Lin, Z.S. \& Gu, C.L. 2006. Multi-scale analysis on China's regional economic diversity and reasons, Economic Research, (7): 117-124.

[4] Chen, X.S. \& Xu, Y. 2004. Factors affecting China's regional gap: An empirical study, Social Science of Chi$n a$, (5): 117-129.

[5] Zhang, W.W. \& Liang, Q. 2011. Geographic concentration of labor, industrial space and regional disparities, Economics, (1): 691-708.

[6] Liu, F.W. 2007. Transfer payments and reducing China's regional inequality, East China Economic Management, (7): $27-29$.

[7] Wang, X.L. \& Fan, G. 2004. Analysis on the regional disparity in China and the influential factors, Economic Research, (1): 33-44.

[8] Li, B. \& Chen, K.J. 2007. Foreign trade and regional economic disparity changes, World Economy, (5): 25-32.

[9] Zhang, T. 2014. Stata Statistic Analysis and Industry Application Cases, Beijing: Tsinghua University Press. pp: 169-206. 